Yıldırım, N. (2020). Öğretmen görüşlerine göre ortaokul öğrencilerinin konuşma kusurları. Ana Dili Eğitimi Dergisi, 8(2), 597-610.

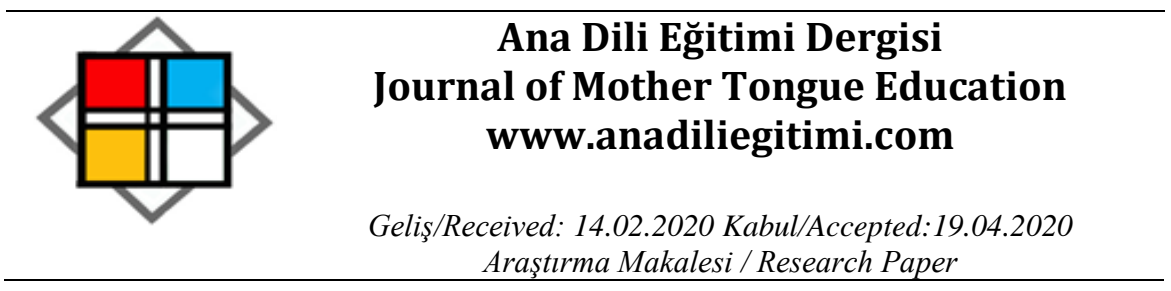

\title{
Öğretmen Görüşlerine Göre Ortaokul Öğrencilerinin Konuşma Kusurları
}

\author{
Nurşen YILDIRIM*
}

\begin{abstract}
Öz
Insanlar, duygu ve düşüncelerini sesler aracılığıyla söze dönüştürerek başkalarına anlatırlar. Bu araştırmada iletişimin vazgeçilmez unsuru olan konuşma üzerinde durulmuştur. Araştırmanın amacı, ortaokul öğrencilerinde $(5,6,7$ ve 8 . sınıflar) gözlemlenen konuşma kusurlarının Türkçe öğretmenlerinin görüşleri ile belirlenmesidir. Bunun için çalışmada araştırmacı tarafından geliştirilen, 7 alt boyutta 44 madde içeren bir anketten yararlanılmıştır. Malatya il merkezinde görev yapmakta olan 50 öğretmenden görüş alınmış ve veriler SPSS 22.0 programı ile analiz edilerek öğrencilerde en sık görülen konuşma kusurları tespit edilmiştir. Buna göre; gelecek zaman 1. tekil kişi çekimini “ -eceğim, -acağım” yerine “-ecem, -acam” şeklinde kullanmak ortaokul öğrencilerinde en fazla görülen konuşma kusurudur. Bu durum hızla ve en az çabayla konuşma isteğinden kaynaklanmaktadır. Ayrıca kısıtlı bir kelime haznesiyle konuşmak, tekrara düşerek konuşmak, konuşurken gereksiz sesler çıkarmak öğrencilerde sık görülen diğer konuşma yanlışlarıdır. Öğrenci konuşmalarında sık gözlemlenen bu üç durum birbiriyle bağlantılı olup kelime dağarcığının kısıtlı olmasından kaynaklanmaktadır. Bireyin sözcük evrenini genişletmek bu üç konuşma kusurunun da giderilmesinde etkili olacaktır.
\end{abstract}

Anahtar Kelimeler: Konuşma, konuşma kusurları, ortaokul öğrencileri

\section{Speech Errors of Secondary School Students According to Teacher Opinions}

\begin{abstract}
People express their feelings and thoughts to others by converting them into words. In this research, speech which is an indispensable element of communication was investigated. This research aims to determine the speech errors observed in secondary school students (the 5th, 6th, 7th, and 8th grades) according to the opinions of Turkish teachers. For this, a questionnaire developed by the researcher containing 44 items in 7 sub-dimensions was used. Opinions of 50 teachers working in Malatya city center were received and data were analysed with SPSS 22.0 program. Later the most common speech errors of the students were identified. Findings of the research revealed that the most common speech error in secondary school students was to shorten the first-person singular conjugation of future tense. This was due to the desire to speak quickly and with minimum effort. In addition, speaking with a limited vocabulary, falling into repetition, making unnecessary voices while speaking are other common speech errors. These three situations which are frequently observed in student' speeches are interconnected and stem from limited vocabulary. Expanding an individual's vocabulary will be effective in eliminating these three speech errors.
\end{abstract}

Keywords: Speech, speech errors, secondary school students

\section{Giriş}

Sözlü iletişim aracı olarak konuşma insanların en önemli ve ayırıcı özeliği kabul edildiğinden insan "konuşan bir varlık" olarak tanımlanır. Konuşma, zihinde biçimlenen düşüncelerin ses organları yardımıyla anlamlı söz kalııına dönüştürülmesidir. Konuşmanın yazılı ifadeye göre en önemli ayrımı doğal koşullar altında ve hazırlıksız yapılmasıdır (Gündüz ve Şimşek, 2014: 17-20).

\footnotetext{
* Doktora Öğrencisi, İnönü Üniversitesi, Eğitim Bilimleri Enstitüsü, Türkçe Eğitimi Bölümü, Malatya, nursen.aksoy.yildirim@gmail.com, ORCID: 0000-0002-1977-9419
} 
Günümüzde özellikle iletişim becerilerinin geliştirilmesi açısından konuşma ve konuşmanın etkileyici gücü yoluyla elde edilen başarı, bireylerin yaşam niteliğiyle doğru orantılı sayılmaktadır. Bu nitelik gerek iş, gerekse özel yaşam boyutunda bireylerin güçlü iletişim kurmaları yoluyla değer kazanacaktır. Değişik amaçlara yönelik yapılan konuşmalar, sunuşlar, toplantılar için geçerli olan ölçütlerin başında etkili konuşma, doğru, anlaşılır ve açık anlatım gelmektedir (Kurudayıoğlu, 2003).

Yaman'a (2007) göre ana dilini iyi bilmek iyi konuşmanın temelini oluşturur. Zihinde var olan ne kadar kavram ve bu kavramlara ilişkin bilgi varsa söylenecekler o kadar çok olur. Duygu ve düşüncelerini etkili biçimde ifade etmek insana sayısız yarar sağlar. Bilgi ve birikimlerini karşı tarafa iletmekte zorlanmak, o bilgileri kullanamamak demektir. Kullanılmayan bilgi ise doğal olarak işlevselliğini yitirir.

Günlük hayatın vazgeçilmez unsurlarından olan konuşmanın niteliği insanlar arasındaki iletişimi ve ilişkiyi etkiler. Konuşmanın niteliğinde etkili olan bazı değişkeler vardır. Dil bilgisi, telaffuz, kelime hazinesi, vurgu ve tonlama, içeriğin sağlam olması, sunum bunlardan bazılarıdır (Bozkurt, 2017; Yıldız ve Yavuz, 2012). Değişkenlerin bir veya birkaçında kusur bulunması konuşmanın kalitesini düşüreceği gibi etkili iletişime de gölge düşürür. Bu nedenle konuşma becerisini geliştirmek adına varsa konuşma kusurlarının belirlenmesi ve düzeltilmeye çalışılması çok önemlidir.

Erdem'e (2013) göre “konuşma, mutabık kalınan işaretlerin ve seslerin karşıdakinin zihninde anlam oluşturmasını, mesaja dönüşmesini sağlayan fiziksel ve zihinsel bir süreçtir. Konuşma, zihnin söz kalıbına döktüğü ve oluşturduğu düşüncelerin, duyguların şekillendirilmesidir. Konuşma, fiziksel anlamda birçok organın birlikte çalışmasıyla ortaya çıkan karmaşık bir beceridir".

Konuşmanın günlük yaşamın bir parçası olduğu çoğu kaynakta ifade edilir. Özdemir’e (2004) göre konuşma, "duygu ve düşünceleri, görülüp yaşananları karşımızdakilere sözle iletme işidir. Konuşma, bir düşünce alışverişi, başka türlü söylemek gerekirse yaşantıları başkalarıyla paylaşma işidir."

İnsanların iletişim halinde olabilmeleri için en önemli unsur konuşmadır. Konuşmayı anlamlı kılabilmek, güçlü aktarım yapabilmek, duygu ve düşünceleri bir insana ya da bir topluluğa doğru biçimde iletebilmek için etkili ve güzel konuşma gerekmektedir (Kurudayıŏlu, 2003).

Konuşma yalnızca fiziksel etkinlik gerektiren yalın bir beceri değildir. Fiziksel ve zihinsel süreçlerin uyumlu, beraber çalışmasını gerektiren karmaşık bir beceridir. Konuşmanın fiziksel ve zihinsel boyutu kendi içinde ayrı ayrı aşamaları barındırır.

Konuşmanın gerçekleşmesi için öncelikle işitme organlarının sağlıklı çalışması gerekir. Fiziksel olarak konuşma yeteneğinin oluşabilmesi için kişinin duyma becerisine sahip olması gerekir. Konuşmada mutabık kalınan dilsel semboller önemli olduğuna göre bunları duyamayan kişinin bu sembolleri algılaması mümkün değildir. Konuşamayanların kendi aralarında ortak bir beden dili geliştirdikleri görülür. Bu da konuşmanın daha doğrusu dilin mutabakat sonucu oluştuğuna en güzel örnektir. Sağırların beden diline hâkim olamayanların onları anlamaları imkânsızdır. Hâlbuki yakın çevresinde sağır kişilerin olduğu bir kimse, onlarla iletişim kurmak zorunda olduğundan onların beden dilini çözebilmektedir (Temizyürek, Erdem ve Temizkan, 2017: 45).

Akciğerlerimizden çıkan havanın sese dönüşerek boğaz, yumuşak damak, küçük dil, dil, diş ve dudakların çeşitli şekillere girerek ünlü, ünsüz sesleri oluşturmasıyla konuşma gerçekleşir (Ömür, 2001: 32). "Yalnızca bu organlar konuşmanın oluşabilmesi için yeterli değildir. Seslerin oluşmasını anlamlı bir konuşmaya dönüştürebilmek için işitme organlarının çalışması, doğru sinir akışları ve beyin işlevleri gerekir" (Erdem, 2013: 417).

Konuşmayı yönlendiren duygu ve düşünceler insan kalbinde başlar. Çünkü konuşma her şeyden önce bir duygu işidir. Kalpten kaynaklanan bu istek beyinde biçimlenir. Ses organları vasıtasıyla ürün durumuna getirilir ve ağız yoluyla dışarıya sunulur. Dolayısıyla konuşmanın biçimlenme aşaması beyinde gerçekleşir. Konuşmayı sevk ve idare eden merkez beyindir. Bu nedenle beyin fonksiyonlarının konuşmadaki önemi büyüktür. Zaten fiziksel bir engeli olmadığı halde konuşma kayıpları yaşanması da zihinsel etkinliklerin yitirilmesiyle açıklanmaktadır (Yaman, 2007: 22).

"Insan, başkalarıyla ilişkilerini sürdürebilmek ve toplum hayatına uyum sağlayabilmek için duygu ve düşüncelerini kendi çevresindeki insanlara aktarmak zorundadır. Iletişim adı verilen bu aktarma eylemi hem biyolojik hem psikolojik olarak bir zorunluluktur. Yapılan araştırmalara göre kişinin çevresiyle en etkili iletişim kurma yolu konuşmadır" (Gündüz ve Şimşek, 2014: 21). 
Konuşmanın bu işlevi etkili, doğru, kusursuz konuşmanın önemini vurgular. Çünkü birey sosyal varlık alanında doğru iletişim sağladığı, kendini iyi ifade ettiği sürece huzurlu olur. O halde duygu ve düşüncelerin doğru aktarımı ancak dil yanlışlarından arınmış, içerik olarak tutarlı ve söyleyişe önem veren akıı bir konuşmayla sağlanır.

Konuşma anlatmaya dayalı dil becerilerinden biridir. Anlatımın sağlanması için öncelikle anlamanın gerçekleşmesi, belli bir bilgi birikimine sahip olunması, dil bilgisi ve bilincinin gelişmiş olması gerekir. Etkili ve güzel bir konuşma fiziksel ve zihinsel süreçlerin sağııkla işlemesine bağlıdır. Ancak her konuşma estetik, içerik, sunum, seslendirme bakımından aynı kalitede değildir. Çünkü konuşma niteliği üzerinde belirleyici olan birden fazla etmen vardır: artikülasyon, entonasyon, vurgu, telaffuz, dilin gramerine hakim olma, beden dili, kaygı düzeyi, kelime hazinesi... Bu etmenlerde yanlış veya eksik bulunması konuşma kalitesini düşürür, iletişimde aksamalara neden olur. Yanlış telaffuzlar, doğru olmayan cümle kuruluşları, hatalı vurgular, kısıtlı sözcük dağarcığı, içeriğin sağlam kurulmaması konuşmayı yanlış bir anlatıma dönüştürür. Oysa etkili ve doğru bir konuşmanın dil yanlışlarından, konuşma bozukluklarından arınmış olması şarttır. Erdem'e (2013) göre "konuşma bozukluğu, konuşmanın akıcılığında, ritminde, vurgularında, zihinsel organizasyonunda sorunlar bulunmasıdır". Konuşmanın niteliğinde bu etmenler belirleyici olduğundan bunlardan birinde veya birkaçında sorun olması konuşma kusuru oluşturur.

Kuru ve Güneş'e (2017) göre konuşma; dil, düşünce, duygu, ses ve konuşma organları gibi öğelerle doğrudan ilgilidir. Bunlardan birinin eksikliği ya da yetersizliği konuşma kusurlarına yol açar. Özgür (2003) ise bu durumu konuşma bozukluğu olarak şöyle değerlendirir: "Konuşma bozukluğu denilince ilk akla gelen akıcılığın bozulması olsa da bunun yanında konuşmaya eşlik etmeyen vücut hareketleri, dinleyicilere uygun hitap edememe, seçilen iletişim yollarının yanlış kullanımı, konuşma konusuna hâkim olamama, dilbilgisi kurallarına uymama gibi problemler de söz konusu olabilir. Ancak konuşma bozuklukları dilin sesli sembolleri, artikülasyon, ses ve işitme olmak üzere geniş bir alanını kapsar".

$\mathrm{Bu}$ araştırmada, ortaokul öğrencilerinde $(5,6,7$ ve 8 . sınıflar) gözlemlenen konuşma kusurlarını tespit etmek amaçlanmıştır. Malatya il merkezindeki ortaokullarda okuyan 10-14 yaş aralığındaki öğrencilerin en fazla hangi konuşma yanlışlarını yaptıkları belirlenmeye çalışılmıştır.

Araştırma, dört temel dil becerileri olan dinleme, konuşma, okuma ve yazmadan sosyal hayatta en yoğun şekilde kullanılan konuşmayı konu edinir. Bu nedenle araştırma sonuçları etkili iletişim kurmanın ve düşünceleri doğru ifade etmenin önündeki engelleri ortaya çıkaracak olması bakımından önemlidir. Bu bağlamda araştırmanın problem cümlesi şudur:

"Ortaokul öğrencilerinde en sık gözlemlenen konuşma kusurları nelerdir?"

Belirtilen problem cümlesi doğrultusunda araştırmada aşağıdaki alt problemlere yanıt aranmıştır:

1. Ortaokul öğrencilerinin konuşmalarında dil bilgisi bakımından hangi kusurlar bulunur?

2. Ortaokul öğrencilerinin konuşmalarında telaffuz bakımından hangi kusurlar bulunur?

3. Ortaokul öğrencilerinin konuşmalarında içerik bakımından hangi kusurlar bulunur?

4. Ortaokul öğrencilerinin konuşmalarında vurgu ve tonlama bakımından hangi kusurlar bulunur?

5. Ortaokul öğrencilerinin konuşmalarında sunum bakımından hangi kusurlar bulunur?

6. Ortaokul öğrencilerinin konuşmalarında yöresel ağız kullanımına bağlı hangi kusurlar bulunur?

7. Ortaokul öğrencilerinin konuşmalarında kelime bilgisi bakımından hangi kusurlar bulunur?

\section{Araştırmanın Modeli}

\section{Yöntem}

Araştırma, nitel araştırma desenlerinden olan durum çalışması (case study) ile yürütülmüştür. "Durum çalışması, güncel bir olguyu kendi gerçek yaşam çerçevesi içinde çalışan görgül bir araştırma yaklaşımıdır" (Yin, 1984'ten akt. Yıldırım ve Şimşek, 2016: 289). Durum çalışması temelde nitel araştırma geleneğinden beslense de yöntemin kendisi nicel verilerin toplanmasına olanak sağlamaktadır (Saban ve Ersoy, 2019: 141). 


\section{Araştırmanın Çalışma Grubu}

$\mathrm{Bu}$ araştırmanın çalışma grubunu Malatya il merkezindeki MEB'e bağlı okullarda görev yapmakta olan 50 Türkçe öğretmeni oluşturmaktadır. Öğretmenler seçilirken cinsiyet dengesi gözetilmemiş yalnızca çalışmaya gönüllü katılım ölçüt alınmıştır. Farklı bölgelerde çalışan öğretmen görüşlerine ulaşmak için il merkezindeki 12 farklı okulda anket uygulanmıştır. 2018-2019 eğitim öğretim yılı ikinci döneminde 32 kadın, 18 erkek öğretmenin katılımıyla çalışma yürütülmüştür. Katılımcıların \% 88'i lisans, \% 8'i yüksek lisans ve \% 2'si doktora eğitim düzeyindedir. Ankete katılan öğretmenlerden 3'ünün mesleki deneyimi 10 yıldan az, 47'sinin mesleki deneyimi ise 10 yıl ve üzeridir. Bu durum öğrencilerindeki konuşma kusurlarını tespit ederken öğretmenlerin uzun yıllara dayanan mesleki bilgi ve birikimlerini işin içine kattıklarını göstermektedir.

\section{Verilerin Toplanması}

Çalışmada, veriler araştırmacı tarafından geliştirilen bir anketle toplanmıştır. Anket hazırlanırken öncelikle kapsamlı bir literatür taraması yapılmış ve konuşma bozukluğu, dil yanlışı veya konuşma kusuru olarak nitelendirilen unsurları içeren bir madde havuzu oluşturulmuştur. Bu havuzdaki maddeler için üç Türkçe eğitimi uzmanından görüş alınmıştır. Uzman görüşleri doğrultusunda birbirini kapsayan maddeler anketten çıkarılmış ve Malatya'nın yöresel ağız özelliklerinden kaynaklanan bazı kullanımların da konuşma kusurları listesine eklenmesi uygun görülmüştür. Anketin geçerlik ve güvenirliğini sağlamak adına her bir maddeye ilişkin uzman görüşleri değerlendirilmiş, bu doğrultuda gerekli düzenlemeler yapılarak görüş birliği sağlanmıştır. Daha sonra üzerinde uzlaşılan 44 madde araştırmanın probleminde belirlenen alt boyutlara uygun olarak 7 başlık altında bir sınıflamaya tabi tutulmuştur. Taslak anket deneme amacıyla 3 Türkçe öğretmenine uygulanmış ve öğretmenlerin açık ve anlaşılır bulmadıkları birkaç ifadede değişikliğe gidilmiştir. Yüz yüze yapılan görüşmelerle, anket uygulanmış ve öğretmenlerden 44 maddelik bir liste halindeki bu ankette öğrencilerde rastladıkları konuşma kusurlarını işaretlemeleri istenmiştir.

\section{Verilerin Analizi}

Araştırmanın amaçları doğrultusunda toplanan veriler SPSS 22.0 veri analiz programı kullanılarak çözümlenmiştir. SPSS paket programı ile anket maddelerinin işaretlenme oranını yüzde olarak belirlenmiştir. 7 alt boyut kendi içerisinde bir değerlendirmeye tabi tutularak ortaokul öğrencilerinde en çok rastlanan konuşma kusurları tespit edilmiştir. Araştırmanın "bulgular" bölümünde anketteki 44 maddenin tamamı bulunmaktadır ve her bir maddenin işaretlenme oranı da tablolar halinde sunulmuştur.

\section{Bulgular}

Bu bölümde araştırmada elde edilen bulgulara ve bunların sonucunda ulaşılan yorumlara yer verilmiştir. Elde edilen bulgular araştırmanın alt problemlerine uygun olarak aşağıda sunulmuştur.

\section{"Dil Bilgisi" Alt Boyutuyla ilgili Bulgular}

Araştırmada veri toplama aracı olarak geliştirilen ankette dil bilgisi alt boyutuyla ilgili 7 konuşma yanış̧ı yer almaktadır. Aşağıdaki tabloya anketteki bu 7 maddenin katılımcılar tarafından öğrencilerinde rastladıklarını belirtme oranları gösterilmiştir.

Tablo 1.

Dil Bilgisi Kaynaklı Konuşma Kusurlarının Analizi

\begin{tabular}{lcc}
\hline Dil Bilgisi Kusurları & $f$ & $\%$ \\
\hline $\begin{array}{l}\text { Gelecek zaman 1. tekil kişi çekimini - eceğim, -acağım yerine } \\
\text { - ecem, -acam şeklinde kullanmak }\end{array}$ & 36 & 72 \\
\hline
\end{tabular}

Tablo 1.

Dil Bilgisi Kaynaklı Konuşma Kusurlarının Analizi (Devamı) 


\begin{tabular}{lcc}
\hline Dil Bilgisi Kusurları & $f$ & $\%$ \\
\hline Konuşmada anlatım bozukluğu yapmak & 24 & 48 \\
Konuşma esnasında birtakım sesleri ve heceleri atlamak & 23 & 46 \\
Ünsüz benzeşmesini konuşmaya yansıtmamak & 17 & 34 \\
Metatez ( göçüşme) yaparak konuşmak & 13 & 26 \\
Ünlü daralmasını konuşmaya yansıtmamak & 13 & 26 \\
Kelime ortasında ses ikizleşmesi yapmak & 12 & 24 \\
İyelik ekini fazladan kullanmak & 6 & 12 \\
Kelime başına kelimenin aslında olmayan ses eklemek & 6 & 12 \\
\hline
\end{tabular}

Tabloda dil bilgisi kaynakı konuşma kusurları öğrencilerde rastlanma oranları bakımından karşılaştırılmıştır. Buna göre ortaokul öğrencilerinde en fazla gözlemlenen konuşma kusuru gelecek zaman 1. tekil kişi çekimini - eceğim, -acağım yerine -ecem, -acam şeklinde kullanmaktır. Hızlı konuşmak ya da en az çabayla konuşmak isteği bu durumun nedeni olarak düşünülebilir. Ayrıca "ğ"nin telaffuzunun öğrencilere zor gelmesi ve söylem anında onu yok sayarak kolay bir söyleyişi tercih etmeleri de bu duruma yol açmış olabilir. Konuşmada anlatım bozukluğu yapmak ve konuşma esnasında birtakım heceleri atlamak öğrencilerde en sık rastlanan diğer dil bilgisi yanlışlarıdır. Buradan öğrencilerin duygu ve düşüncelerini ifade etmede kestirme söylemler tercih ettiği ve bu nedenle cümlelerin anlatım olarak sağlamlıktan uzaklaştığı çıkarılabilir. Tabloya göre öğrencilerin konuşma anındaki genel yaklaşımı kelimede bulunan bazı sesleri seslendirmekten kaçınarak kısa söyleyişlere yönelmektir.

\section{"Telaffuz" Alt Boyutuyla ilgili Bulgular}

Her harfin konuşma organlarındaki oluşum ve temas noktası farklıdır. Ünlüleri ve ünsüzleri çıkış noktalarına uygun seslendirmek gerekir. Harflerin gerekli ve doğru yerlere temas edilmeden söylenmesi telaffuz yanlışlığı oluşturur.

Tablo 2.

Telaffuz Kaynaklı Konuşma Kusurlarının Analizi

\begin{tabular}{lcc}
\hline Telaffuz Kusurları & $\mathrm{f}$ & $\%$ \\
\hline Kelimeleri yanlış telaffuz etmek & 25 & 50 \\
Harfleri çıkış yerlerine, boğumlamaya dikkat etmeden seslendirmek & 13 & 26 \\
Kelimeleri ağzından tam çıkarmamak & 9 & 18 \\
Kelimeyi yarıya kadar seslendirip tekrar başa dönmek & 6 & 12 \\
Konuşmada " $r$ " seslerini çıkartamamak & 5 & 10 \\
Konuşmada "s" seslerini peltek söylemek & 4 & 8 \\
"r" sesi yerine "y" sesini telaffuz etmek & 4 & 8 \\
\hline
\end{tabular}

Tabloya göre ortaokul öğrencilerinin en çok yaptığı telaffuz yanlışı kelimeleri doğru seslendirmemektir. Bunda öğrencinin yakın çevresinden yanlış kullanımları duya duya yanlışı doğru zannetmesi etkili olabilir. Örneğin; öğrenci "eşofman" yerine "aşortman" diyorsa, çevresindeki yetişkinler de kelimeyi böyle kullanıyorsa yanlış devam eder. Çünkü birey herkesten duyduğu yanlış kullanımı doğru sanmaktadır. Bu yanlış örnek zincirinin bir yerde kırılması gerekir. Ancak o zaman öğrenci yanlış telaffuzunu fark eder ve kelimeyi doğru seslendirmeye çabalar. Harfleri çıkış yerlerine uygun seslendirmemek ve kelimeleri ağızdan tam çıkarmamak öğrencilerin yaptığı diğer telaffuz yanlışlarıdır.

Telaffuz yanlışlarını gidermenin en etkili yolu bireye bol bol doğru örnekler sunmaktır. Çünkü birey dinler, dinlediklerini zihninde kodlar ve belli bir birikimden sonra konuşur. Ayrıca radyo ve televizyonlarda güzel konuşan bilim adamlarını, spikerleri dinlemek de telaffuz konusunda kişiye bir 
bilinç kazandırabilir. Harflerin doğru telaffuzu için ise tekerlemelerden yararlanılabilir. Çünkü tekerlemeler bir nevi dil egzersizleridir.

\section{"içerik" Alt Boyutuyla ilgili Bulgular}

Konuşmanın içeriği, konuşmacının konuyu nasıl işlediği ile ilgilidir. Konunun düzenlenme ve aktarılma biçimi konuşmanın karakteri üzerinde belirleyici olur.

Tablo 3.

içerik Kaynakı Konuşma Kusurlarının Analizi

\begin{tabular}{lcc}
\hline İçerik Kusurları & $f$ & $\%$ \\
\hline Konuşmasını bir plan dâhilinde gerçekleştirmemek & 22 & 44 \\
Konudan uzaklaşarak, konu dışına çıkarak konuşmak & 17 & 34 \\
Konuşma konusu ile alakasız örnekler vermek & 16 & 32 \\
Konuşma içeriğinde tutarsızık, çelişkili anlatımlar bulunması & 14 & 28 \\
Olayları veya bilgileri sıraya koyarak anlatmamak & 11 & 22 \\
Konuşmasında geçiş ve bağlantı ifadelerini yerinde kullanmamak & 10 & 20 \\
Konuşmasında argo ifadelere yer vermek & 9 & 18 \\
\hline
\end{tabular}

Tabloya göre en fazla rastlanan konuşma kusuru konuşmanın bir plandan yoksun oluşudur. Konu dışına çıkmak ve alakasız örnekler vermek de en çok gözlemlenen diğer yanlışlardır. Oysa yazıda olduğu gibi konuşmada da bir plan bulunmalıdır, ana fikir yardımcı fikirlerle desteklenmeli, örnekler verilmelidir. Ancak tablodan anlaşıldığı üzere ortaokul öğrencileri konuşmalarını bir plan dâhilinde değil de gelişigüzel yürütmeyi tercih etmektedir. Konuların öncelik, sonralık sırasını göz ardı ederek konuşmak ifadeyi dağıtır. Bu plansızlık birkaç söylem sonra konu dışına çıkmayı da beraberinde getirir. Bunu önlemek için konuşma öncesi zihinsel bir tasarlama yapmak yerinde olacaktır. Konuşmanın zihinsel sürecini olabildiğince hızlı yürütmek, konuşurken bir taraftan da zihinde düzenleme yapmak, ilgili parçaları yan yana getirmek plansız konuşmayı önler.

\section{"Vurgu ve Tonlama" Alt Boyutuyla ilgili Bulgular}

Vurgu ve tonlama, bazı kelimelerin veya hecelerin daha baskılı söylenmesiyle cümleye çeşitli anlam incelikleri sağlar. Vurgu yerli yerine oturtulmadıkça istenilen anlam ortaya konamaz.

Tablo 4.

Vurgu ve Tonlama Kaynaklı Konuşma Kusurları

\begin{tabular}{lccc}
\hline Vurgu ve Tonlama Kusurları & $\mathrm{f}$ & $\%$ \\
\hline Konuşmasında vurgu ve tonlama yanlışları yapmak & 19 & 38 \\
Konuşmada duraklamaları noktalama işaretlerine uygun yapmamak & 17 & 34 \\
Anlaşılmayı güçleştirecek kadar hızlı konuşmak & 7 & 14 \\
Anlaşılmayı güçleştirecek kadar yavaş konuşmak & 4 & 8 \\
\hline
\end{tabular}

Tabloda ortaokul öğrencilerinde en sık görülen konuşma yanlışı vurgu ve tonlamayı yanlış yapmak olarak belirlenmiştir. Yani öğrenciler cümleye anlatılmak istenen duyguyu katmadan, tek düze konuşmaktadır. Kelime ve heceler arasında yükseklik ve yoğunluk bakımından sesin alçalıp yükselmeyişi monoton bir konuşmaya neden olur. Bunu önlemek için öncelikle ses organları etkili kullanılmalıdır. Gereken yerde durak, vurgu ve entonasyon yapmak için nefes egzersizleri de faydalı olabilir. Nefes kontrolünün sağlanmasıyla konuşmaya etkililik, duygu, heyecan kazandırılabilir. 


\section{"Sunum" Alt Boyutuyla ilgili Bulgular}

Sunum konuşmacının o anki psikolojik durumu, tavır ve davranışlarıyla doğrudan ilgilidir. Konuşma esnasında rahat olmamak, aradığı kelimeyi zihninde bulamayarak gereksiz sesler çıkarmak, anlattıklarını beden diliyle desteklememek konuşma niteliğini olumsuz etkiler.

Tablo 5.

Sunum Kaynaklı Konuşma Kusurları

\begin{tabular}{lcc}
\hline Sunum Kusurları & $\mathrm{f}$ & $\%$ \\
\hline Konuşurken gereksiz sesler çıkarmak & 25 & 50 \\
Konuşurken jest ve mimiklerini, beden dilini etkili kullanmamak & 22 & 44 \\
Konuşma sırasında kaygııı hissetmek & 21 & 42 \\
Konuşurken öne arkaya veya iki yana sallanmak & 20 & 40 \\
Dinleyicilerle göz teması kurmamak & 19 & 38 \\
Konuşmaya isteksiz olmak & 16 & 32 \\
Açık, net, anlaşılır bir sesle konuşmamak & 8 & 16 \\
Konuşma esnasında duyulmayacak kadar kısık ses tonu kullanmak & 6 & 12 \\
Konuşmada gereksiz yere bağırmak & 6 & 12 \\
\hline
\end{tabular}

Tabloya göre ortaokul öğrencilerinde en yaygın görülen konuşma kusuru konuşurken gereksiz sesler çıkarmaktır. Bu durum öğrencilerin aradıkları kelimeyi zihinlerinde hemen bulamadıkları, söz arasında oluşan boşlukları doldurmak adına "asalak ses" olarak tabir edilen "hımmm, şeyyy, eeee, ıIıı" benzeri sesler çıkardıklarını gösterir. Konuşma esnasında kaygılı hissetmek ve beden dilini etkili kullanmamak öğrencilerde sıkça karşılaşılan diğer konuşma kusurlarıdır. Bireyin özgüven eksikliği konuşurken kaygı duymasına neden olur. Öğrencilerin motivasyon düzeyinin yükseltilmesi, onlara olumlu telkinde bulunmak konuşma kaygısını azaltacaktır.

\section{"Yöresel Ağız Kullanımı" Alt Boyutuyla ilgili Bulgular}

"Yöresel ağız özelliklerine göre konuşmada seslerle ilgili yanlış kullanımlar olabileceği gibi ek ve kelimelerde de yanlışlar görülebilir. Yazılı dilde ve İstanbul ağzında olmayan pek çok unsurun sözlü dilde mahallileştiği görülür" ( Erdem, 2013: 442).

Tablo 6.

\begin{tabular}{|c|c|c|}
\hline Yöresel Ağız Kullanımım Kusurları & $f$ & $\%$ \\
\hline $\begin{array}{l}\text { Şimdiki zaman eki “-yor” yerine yöresel söyleyişten kaynaklı “-yı, } \\
\text {-yi, -yu, -yü” eklerini kullanmak }\end{array}$ & 20 & 40 \\
\hline " $\mathrm{k}$ " sesleri yerine yöresel ağzın özelliğinden "g" sesini kullanmak & 15 & 30 \\
\hline $\begin{array}{l}\text { Kelimenin aslında olmayan bazı sesleri sesletim esnasında kelime sonuna } \\
\text { eklemek }\end{array}$ & 11 & 22 \\
\hline Ayrılma hal eki "+den, + dan" yerine bulunma hal eki olan " + de, + da" kullanmak & 7 & 14 \\
\hline Kelimelerin başındaki " $h$ " sesini söylememek & 3 & 6 \\
\hline
\end{tabular}

Tabloya göre öğrencilerde en sık rastlanan konuşma kusurları "şimdiki zaman eki '-yor' yerine '-yı, -yi, -yu, -yü' eklerinden birini kullanmak" ve " özellikle kelime başlarındaki ' $k$ ' sesleri yerine ' $\mathrm{g}$ ' sesini kullanmak" tır. Bu kullanım Malatya yöresinin en belirgin ağız özelliğidir. Çevresindeki yetişkinlerden bu tarz kullanımlar duymanın öğrenciye doğrudan örnek olduğu görülmektedir. İstanbul Türkçesi ile hazırlanmış dinleme metinlerini örnek olarak kullanmak; yöresel 
kullanım özellikleri içermeyen açık, net, düzgün bir konuşmayla öğrencilere örnek olmak bu tarz konuşma yanlışlarının giderilmesinde yardımcı olabilir. Çünkü birey doğru kullanımı duya duya zihnine yerleştirecek ve ardından düzgün bir ifade tarzına doğru yönelecektir.

\section{"Kelime Bilgisi" Alt Boyutuyla İlgili Bulgular}

Kelimeler bireyin düşünce evrenini oluşturur. Bireyin dünyaya bakış açısı bildiği kelimelerle sınırlıdır. Bu nedenle duygu ve düşüncelerin doğru aktarılması kelime hazinesiyle doğrudan ilgilidir.

Tablo 7.

Kelime Bilgisi Kaynaklı Konuşma Kusurları

\begin{tabular}{lcc}
\hline Kelime Bilgisi Kusurları & $\mathrm{f}$ & $\%$ \\
\hline Kısıtı bir kelime haznesiyle konuşmak & 33 & 66 \\
Tekrara düşerek konuşmak & 28 & 56 \\
Kelimeyi cümlede anlamına uygun olarak kullanmamak & 8 & 16
\end{tabular}

Tabloya göre kısıtlı bir kelime hazinesiyle ve tekrara düşerek konuşmak ortaokul öğrencilerinde en sık rastlanan konuşma kusurlarıdır. Buna göre sınırlı bir sözcük dağarcığına sahip olan bireylerin konuşurken tekrara düşmesi kaçınılmazdır. Bireyin sözcük evrenini genişletmek bu iki problemi de ortadan kaldıracaktır. Çünkü ne kadar çok kelime ve kavram bilinirse duygu ve düşünceler o denli rahat ifade edilir. Bunun için bol bol kitap okumak önerilebilir. Türk ve Dünya edebiyatının seçkin eserlerinin okunması hem kelime hazinesini geliştirir hem de dilin güzel kullanımlarını kazandııı. Kelime hazinesini genişletmenin bir yolu da bulmaca çözmektir. Böylece hem bilgiler gelişir hem de yeni kelimeler öğrenilir. Anlamı bilinmeyen kelimeler için sık sık sözlüklere başvurmak, yazımı karıştııılan kimi sözcükleri Yazım Kılavuzu'ndan araştırmak da kelime hazinesini zenginleştirecek diğer bazı etkinliklerdir.

\section{Tartışma ve Sonuç}

Ortaokul öğrencilerinde rastlanan konuşma yanlışlarını belirlemeyi amaçlayan bu çalışmada öğretmen görüşlerinden yararlanılmıştır. Araştırmacı tarafından geliştirilen 44 maddelik anket Malatya il merkezinde görev yapmakta olan 50 Türkçe öğretmenine uygulanmıştır. Elde edilen veriler en fazla rastlanan konuşma yanlışlarını bulmak üzere SPSS 22.0 programı kullanılarak analiz edilmiş, yalnızca konuşma kusurlarının yüzdelik oranları belirlenmiş, ilişkilendirme yoluna gidilmemiştir. Araştırma neticesine göre ortaokul öğrencilerinde en sık rastlanan konuşma kusurları sırasıyla şunlardır:

1. Gelecek zaman 1. tekil kişi çekimini - eceğim, -acağım yerine - ecem, -acam şeklinde kullanmak

2. Kısıtlı bir kelime haznesiyle konuşmak

3. Tekrara düşerek konuşmak

4. Konuşurken gereksiz sesler çıkarmak

5. Kelimeleri yanlış telaffuz etmek

Bu tespit yapılırken ankette yer alan 44 madde içerisinde öğrencilerde gözlendiği en fazla belirtilen 5 madde sırasıyla verilmiştir. Gelecek zaman 1. tekil kişi çekimini -eceğim, -acağım yerine ecem, -acam şeklinde kullanmak ve kelimeleri yanlış telaffuz etmek öğrencinin çevresinden yanlış örnekler duyduğunu gösterir. Çünkü konuşmanın ilk aşaması dinlemedir. Birey dinlediklerini kodlayarak zihnine yerleştirir ve belli bir süre sonra zihnindeki dil malzemelerini konuşmasına yansıtır. Demir ve Özdil'in (2019) öğretmen görüşlerinden hareketle öğrencilerin konuşma becerilerini yokladıkları çalışmada; argo kullanımına, söz varlığı yetersizliğine, düşük sosyoekonomik yapının yansımalarına, ders kitaplarındaki konuşma etkinliklerinin yetersizliğine, öğrenci merkezli sınıf ortamlarının oluşturulamadığına yönelik katılımcı görüşleri dikkat çekicidir. Yine bu çalışmada 
öğrencilerin aile ortamının etkisiyle mahalli unsur özellikleri ile konuştuğu ve ölçünlü dil özelliklerine hâkim olmadığı dile getirilmiştir.

Öğrencilerde konuşma kusuru olarak en sık gözlemlenen üç durum birbiriyle bağlantılı olup kelime dağarcığının kısıtlı olmasından kaynaklanmaktadır. Çünkü öğrenci kelime hazinesi zengin olmadığı için tekrara düşerek konuşur. Yine kelime hazinesi kısıtlı olduğundan aradığı kelimeyi zihninde bulamaz ve zaman kazanmak için söz arasındaki boşlukları "hımm, III, şeyyy, eeee" gibi gereksiz seslerle doldurur. Böylece akıcı bir konuşmadan uzaklaşılır. Güneş ve Kuru (2017) , akıcı konuşma problemine dikkat çektikleri nicel çalışma neticesinde bu problemi yaşayan öğrencilerin etkinlikler sonrasında kelime hazinelerindeki gelişim ve cümlede kullandıkları kelime sayısındaki artışın dakikada kullanılan hece sayılarını da artırdığına değinmişlerdir.

Çalışmada ulaşılan sonuçlara benzer şekilde Çal ve Erdoğan (2017), çalışmalarında Türkçe öğretmeni adaylarının konuşma esnasında kendilerini ifade etmekte zorlandıklarını, yetersiz bilgiye sahip olmalarının bu durumu artırdığını, topluluk önünde çok fazla konuşmadıkları için konuşma becerisinin gelişemediğini vurgulamış aynı zamanda öğretmen adaylarının telaffuz ve tonlama konusunda her ne kadar hassas olsalar dahi hata yaptıklarını, yerel ağızlarla konuşan öğrencilerin olduğunu ve sosyal medyadan konuşma anlamında olumsuz etkilendiklerini tespit etmişlerdir. Ayrıca Özden (2018), 244 lisans öğrencisiyle yürüttüğü çalışmada öğrencilerin konuşma becerisi öz yeterlik alt boyutlarından en çok konuşma değerlendirme, en az topluluk önünde konuşma yeterliliklerine sahip olduklarını düşündüklerini belirlemiştir. Akkaya (2012), konuşma sorunlarını çözmek için konuşma kusurlarını tespit etmek gerektiği görüşünden hareketle öğretmen adaylarının konuşma sorunlarının neler olduğunu araştırmıştır. Araştırma sonucunda öğretmen adaylarında ses, ton, vurgu, telaffuz yanlışları; topluluk karşısında konuşamama, birebir ilişkilerde konuşama; konuşma duraksaması; dil bilgisi kurallarına uyulmaması, bilgi eksikliği, konuşmaya odaklanamama ve fiziksel nedenlerden kaynaklanan konuşma sorunlarının görüldüğü belirlenmiştir.

Ortaokulda konuşma öğretimi Türkçe ders kitapları ile yürütülmektedir. Ancak alan yazın incelendiğinde bazı çalışmalarda ortaokul Türkçe ders kitabındaki konuşma etkinliklerinin yetersiz bulunduğu görülmüştür (Benzer ve Ünsal, 2019; Demir ve Özdil, 2019). Benzer ve Ünsal (2019), ders kitabında sunulan konuşma etkinlikleriyle ilgili öğretmen görüşlerinden elde edilen bulgular ışığında öğretmenlerin \%67'sinin yönerge eksikliği, öğrencinin ilgisini çekememe, fazla zaman gerektirme gibi nedenlerden ötürü ders kitabında yer alan etkinlikleri yetersiz bulduğunu belirlemiştir. Oysa konuşma yanlışlarını gidermede etkinliklerin ne kadar önemli olduğunu Kuru ve Güneş (2017) çalışmalarında ortaya koymuştur. Nitekim Kurudayıoğlu'na (2003: 307) göre "Sınıfta uygulanacak etkinlikler konuşma eğitiminin zihinsel süreçlerini ve fiziksel unsurlarına yönelik olan diksiyonu geliştirici mahiyette olabilir. Sınıfın seviyesi ve kazanımlar göz önünde bulundurularak iyi yapılandırımış etkinliklerle öğrencilerin konuşma becerilerinin âdeta oyun havası içinde geliştirilebilir". Bu nedenle ortaokul Türkçe ders kitaplarında konuşma ötelenmemeli; tıpkı okuma, yazma ve dinleme etkinlikleri oranında yer almalıdır.

Konuşmanın fiziksel ve zihinsel iki yönlü kompleks bir beceri olduğunu dikkate almak gerekir. Ancak bu sayede konuşmayı aksatan sebep doğru belirlenebilir. Dil yanlışlarını düzeltmek için kişileri yazılı metinlere yönlendirmek önemlidir. Bol bol okuma alıştırmaları ile öğrencileri Türk ve Dünya edebiyatından seçkin metinlerle karşılaşmak yararlı olacaktır. Kelime hazinesini zenginleştirmek için öğrenciler yazım kılavuzu ve sözlük kullanmaya özendirilmelidir.

Öğrencilerde Türkçenin fonetik özellikleriyle ilgili farkındalık oluşturmak gerekir. Çünkü fonetik söyleyişi tamamlar. Tekerlemelerden öğrencilerin telaffuz becerilerini geliştirme amacıyla yararlanılabilir. Hangi harf kusurlu telaffuz ediliyorsa o harften çok sayıda içeren bir tekerleme söyletilebilir. Çünkü tekerlemelerde zihin anlama odaklanmaz, sadece doğru söyleyişe çabalar. Bazı kelime oyunlarından telaffuz kusurlarını giderme amacıyla yararlanılabilir. Oyunu belirleyip geliştirirken öğrencilerin yaş ve seviyesini dikkate almak yararlı olacaktır.

Konuşma kaygısını gidermek için rahat bir sınıf ortamı oluşturulmalı ve öğrencilerin duygu ve düşüncelerini ifade etmelerine olanak tanınmalıdır. Drama çalışmaları ile özellikle özgüven problemi yaşayan öğrencilere konuşmada beden dilinin etkili kullanımı, jest ve mimiklerin uyumu öğretilebilir. Grup çalışmaları ile öğrencilerin hazırlıklı ve hazırlıksız konuşma yapmaları sağlanabilir. Bu 
çalışmalarla konuşmanın özellikle sunum ve içerik boyutuyla ilgili dönüt vermek öğrenciyi geliştirecektir.

Akıcı bir konuşmayı sağlamak ve gereksiz sesler çıkarmayı önlemek için hafızayı güçlendirecek etkinlikler yapılabilir. Bunun için kavram ağı oluşturma, şifreleme, sınıflandırma gibi yöntemler kullanılabilir.

Yöresel ağız kullanımlarını en aza indirmek için öncelikle öğrencilere doğru örnekler sunmak gerekir. Ayrıca radyo ve televizyonlarda düzgün konuşan spikerler, araştırmacılar dinlenebilir. Çünkü öğrenci düzgün konuşmaları duya duya zihnine doğru kullanımı kodlayacaktır.

\section{Kaynaklar}

Akkaya, A. (2012). Öğretmen adaylarının konuşma sorunlarına ilişkin görüşleri, Mustafa Kemal Üniversitesi Sosyal Bilimler Enstitüsü Dergisi, 9(20), 405-420.

Aktaş, Ş. ve Gündüz, O. (2001). Yazılı ve sözlü anlatım, Ankara: Akçağ Yayınları.

Benzer, A. ve Ünsal, F. (2019). Konuşma öğretiminin program ve ders kitabı ekseninde uygulamaya yansıması.

Ana Dili Eğitimi Dergisi, 7(3), 647-662.

Bozkurt, B. Ü. (2017). Türkçe anadili konuşucuları için konuşma becerisi değerlendirme çerçevesi önerisi. Ana Dili Eğitimi Dergisi, 5(4), 924-947.

Çakan, M. ve Gül, G. (2018). Ses eğitiminde kullanılan nefes ve ses egzersizlerinin konuşma bozukluklarının giderilmesinde kullanılabilirliği. Afyon Kocatepe Üniversitesi Akademik Müzik Araştırmaları Dergisi, 4(8), 50-63.

Çal, P. ve Erdoğan, E . (2017). Türkçe eğitimi bölümü öğretmen adaylarının konuşma ve yazma becerileri hakkında öğretim üyesi görüşleri. Aydın Tömer Dil Dergisi, 2(2), 1-15.

Demir, S. ve Gül Özdil, B. (2019). Öğretmen görüşlerine göre ortaokul öğrencilerinin konuşma becerileri. Bolu Abant izzet Baysal Üniversitesi Eğitim Fakültesi Dergisi, 19(3). 865-881.

Erdem, i. (2013). Konuşma eğitimi esnasında karşılaşılan konuşma bozuklukları ve bunları düzeltme yolları. Adıyaman Üniversitesi Sosyal Bilimler Enstitüsü Dergisi, Türkçenin Eğitimi Öğretimi Özel Sayısı, 6(11), 415-452.

Gündüz, O. ve Şimşek, T. (2014). Anlatma teknikleri 2 uygulamalı konuşma eğitimi. Ankara: Grafiker Yayınları.

Güneş, F. (2014). Konuşma öğretimi yaklaşım ve modelleri. Bartın Üniversitesi Eğitim Fakültesi Dergisi. 3(1).

Hamzadayı, E. ve Dölek, O. (2017). Konuşma becerisinin değerlendirilmesinde Türkçe öğretmenlerinin yaklaşımları. Dil Eğitimi ve Araştırmaları Dergisi, 10( 3), 135-151.

Hamzadayı, E., Bayat, N. ve Gölpınar, Ş . (2018). Konuşma kaygı düzeyi ile konuşma başarımı arasındaki ilişki. Dil Eğitimi ve Araştırmaları Dergisi, 4 (2) , 75-85.

Kuru, O. ve Güneş, F. (2017). Akıcı konuşma problemi yaşayan ilkokul 4. sınıf öğrencilerinin konuşma becerilerinin geliştirilmesi. Erzincan Üniversitesi Eğitim Fakültesi Dergisi, 19 (1) , 33-47.

Kurudayıoğlu, M. (2003). Konuşma eğitimi ve konuşma becerisini geliştirmeye yönelik etkinlikler. Türklük Bilimi Araştırmaları-13, Türkçenin Öğretimi Özel Sayısı, Bahar, 287- 309.

Muallimoğlu, N. (2005). Bütün yönleri ile hitabet. (7. Baskı). İstanbul: Avcıol Basım Yayın.

Nuhoğlu M., Taş, H., Karakuş, E., ve Gökkaya, H. (2015). Türkçe öğretimi uygulamaları. (2. Baskı). Ankara: Nobel Yayıncilık.

Ömür, M. (2001). Sesin peşinde . İstanbul: Pan Yayıncılık.

Özdem, Y. (2003). Konuşma sanatı, diksiyon. İstanbul: Kariyer Yayıncılık.

Özdemir, E. (2004). Güzel ve etkili konuşma sanatı. İstanbul: Remzi Kitabevi.

Özden, M. (2018). Türkçe eğitimi lisans öğrencilerinin konuşma becerisi öz yeterlikleri. Uluslararası Türkçe Edebiyat Kültür Eğitim Dergisi, 7(3). 1917-1930.

Özgür, ì. (2003). Konuşma bozuklukları ve sağaltımı. Adana: Nobel Yayınevi

Saban, A. ve Ersoy, A.(Editörler). (2019). Eğitimde nitel araştırma desenleri. (3. Baskı).Ankara: Anı yayıncılık.

Şenbay, N. (2000). Söz ve diksiyon sanatı. (7. Baskı). İstanbul: Yapı Kredi Yayınları. 
Temizyürek, F. , Erdem, i. ve Temizkan, M. (2017). Konuşma eğitimi. (7. Baskı). Ankara: Pegem Akademi

Yaman, E. (2007). Konuşma sanatı. ( 4. Baskı). Ankara: Gazi Kitabevi.

Yıldırım, A. ve Şimşek, H. (2016). Sosyal bilimlerde nitel araştırma yöntemleri. Ankara: Seçkin Yayıncilık.

Yıldız, Ç. D. ve Yavuz, M. (2012). Etkili bir konuşma ölçeği: bir ölçek geliştirme çalışması. Turkish studies, 7(2). 319-334.

\section{Introduction}

\section{Extended Abstract}

The quality of speech which is one of the indispensable elements of daily life affects the communication and relationship between people. Some of the variables affecting the quality of speech can be named as grammar, pronunciation, vocabulary, emphasis and intonation, content, and presentation. Having flaws in one or more of the variables will degrade the quality of speech and hinder an effective communication. Therefore, in order to improve speech skills, it is very important to identify and correct the speech errors, if any.

This study aims to detect speech errors observed in secondary school students (the 5th, 6th, 7 th and 8th grades). This research was carried out in Malatya city center. The research focuses on the speech which is one of four basic language skills, and most widely used in social life. For this reason, research results are important in terms of moving the barriers to effective communication and expressing thoughts correctly.

\section{Method}

The research was designed as case study which is a qualitative research design. In this research, the data were collected by a questionnaire developed by the researcher. While preparing the questionnaire, a comprehensive literature review was conducted and a 44-item questionnaire containing speech errors was created. In order to ensure the validity and reliability of the questionnaire, expert opinions were obtained about each item, and consensus was made by making necessary arrangements in this direction. Subsequently, the agreed items were classified under 7 titles in accordance with the sub-dimensions determined in the problem of the research: grammar, pronunciation, content, emphasis and intonation, presentation, local mouth use, vocabulary. In the second term of 2018-2019 academic year 50 Turkish teachers in Malatya were participated in the study. The questionnaire was applied through face-to-face interviews, and teachers were asked to mark the speech errors they encountered in this questionnaire. Data were analyzed by using the SPSS 22.0 data analysis program. With SPSS package program, the rate of marking the questionnaire items was determined as a percentage. The 7 sub-dimensions were investigated within themselves, and the most common speech errors were identified in secondary school students.

\section{Result and Discussion}

According to the research results, the most common speech errors among secondary school students are as follows:

1. Shortening the first-person singular conjugation of future tense

2. Speaking with limited vocabulary

3. Falling into repetition while speaking

4. Making unnecessary sounds while speaking

5. Mispronunciation of words

It was determined through the 5 items which were the most frequently observed in students. The use of the 1st person singular conjugation in the future tense and mispronunciation indicate that the student heard wrong examples from his language environment. Because the first stage of speech productions is listening. An individual encodes what he listens to, places it in his mind and after a certain period reflects the language materials in his mind to his speech. 
Three most frequently observed speech errors in students are related to each other and were related to limited vocabulary. Since the student's vocabulary is not rich, he talks repeatedly. Again, since his vocabulary is limited, he is unable to find the word he is looking for in his mind and uses unnecessary voices as gap-fillers to save time. Therefore, speech is not performed fluently.

The first stage of the conversation is to listen. Therefore, it is necessary to raise awareness about the phonetic features of Turkish and give students correct examples in terms of speaking. Directing people to written texts to correct speech errors is recommended. It is also suggested to practice reading with selected texts from Turkish and World literature. Students should be encouraged to use a spelling guide and dictionary to enrich their vocabulary. Rhymes can be used to improve students' pronunciation skills. A rhyme related to an incorrectly pronounced letter can be said more often. Because in rhymes, mind does not focus on comprehending, but tries to say correctly. With group work, students can perform rehearsed or unrehearsed speech. Giving feedback about presentation and content dimension of the speech with these activities will improve students' speech production and prevent them from making unnecessary sounds during the speech. 


\section{EK 1. Ortaokul Öğrencilerinin Konuşma Kusurlarını Belirleme Anketi}

\section{BÖLÜM: KişiSEL BİLGILER}

1. Cinsiyetiniz : () Kadın () Erkek

2. Eğitim Düzeyiniz: () Lisans () Yüksek Lisans ( ) Doktora

3. Meslekte kaçıncı yılınızdasınız?

2.BÖLÜM: ORTAOKUL ÖĞRENCILERININ KONUŞMA KUSURLARININ BELIRLENMESi

\begin{tabular}{|c|c|c|c|}
\hline $\begin{array}{c}\text { Alt } \\
\text { Boyutlar }\end{array}$ & Anket Maddeleri & Evet & Hayır \\
\hline \multirow{9}{*}{ Dil Bilgisi } & İyelik ekini fazladan kullanır. (onun evisi, kızın adısı) & & \\
\hline & Ünlü daralmasını konuşmaya yansıtmaz. (sevmiyor-sevmeyor) & & \\
\hline & $\begin{array}{l}\text { Kelimenin aslında olmayan bazı harfleri sesletim esnasında kelime } \\
\text { başına ekler.(ramazan-iramazan) }\end{array}$ & & \\
\hline & $\begin{array}{l}\text { Kelime ortasında ses ikizleşmesi yapar. (iğne-inne, sabahtan } \\
\text { beri- sabahtan belli) }\end{array}$ & & \\
\hline & $\begin{array}{l}\text { Metatez (göçüşme) yaparak konuşur. (kibrit-kirbit, kamyon- } \\
\text { kaymon) }\end{array}$ & & \\
\hline & $\begin{array}{l}\text { Gelecek zaman 1. tekil kişi çekimini -eceğim, -acağım yerine - } \\
\text { ecem, -acam şeklinde kısaltarak kullanır. }\end{array}$ & & \\
\hline & $\begin{array}{l}\text { Konuşma esnasında bir takım sesleri ve heceleri atlar. } \\
\text { (allahaısmarladık - alasmaladık, Galatasaray-Gassaray) }\end{array}$ & & \\
\hline & Konuşmasında anlatım bozuklukları yapar. & & \\
\hline & $\begin{array}{l}\text { Ünsüz benzeşmesini konuşmasına yansıtmaz. (gerçekten- } \\
\text { gerçekden, sınıfça-sınıfca) }\end{array}$ & & \\
\hline \multirow{7}{*}{ Telaffuz } & $\begin{array}{l}\text { Kelimeleri yanlış telaffuz eder. (eşofman-aşortman, ceket- } \\
\text { çeket, vişne-- fişne) }\end{array}$ & & \\
\hline & $\begin{array}{l}\text { Harfleri çıkış yerlerine, boğumlamaya dikkat etmeden } \\
\text { seslendirir.(gırtlak, dudak, çene, dil, boğaz, damak tembelliği) }\end{array}$ & & \\
\hline & Kelimeleri ağzından tam çıkarmaz. & & \\
\hline & Konuşmada " $r$ " seslerini çıkartamaz. $\quad$ (araba-aaba) & & \\
\hline & Konuşmada "s" seslerini peltek sesletir. & & \\
\hline & Kelimeyi yarıya kadar seslendirip tekrar başa döner. & & \\
\hline & "r" sesi yerine "y" sesini telaffuz eder. (arı-ayı, rakam-yakam) & & \\
\hline \multirow{7}{*}{ İçerik } & Konudan uzaklaşarak, konu dışına çıkarak konuşur. & & \\
\hline & Konuşma konusu ile alakasız örnekler verir. & & \\
\hline & Konuşmasını bir plan dâhilinde gerçekleştirmez. & & \\
\hline & Konuşmasında geçiş ve bağlantı ifadelerini yerinde kullanmaz. & & \\
\hline & Konuşmasında argo ifadelere yer verir. & & \\
\hline & Konuşma içeriğinde tutarsızlık, çeliş̧kili anlatımlar gözlenir. & & \\
\hline & Olayları veya bilgileri sıraya koyarak anlatmaz. & & \\
\hline \multirow{4}{*}{$\begin{array}{l}\text { Vurgu ve } \\
\text { Tonlama }\end{array}$} & Konuşmasında vurgu ve tonlama yanlışları gözlenir. & & \\
\hline & Konuşmada duraklamaları noktalama işaretlerine uygun değildir. & & \\
\hline & Anlaşılmayı güçleştirecek kadar hızlı konuşur. & & \\
\hline & Anlaşılmayı güçleştirecek kadar yavaş konuşur. & & \\
\hline \multirow[b]{5}{*}{ Sunum } & Konuşurken gereksiz sesler çıkarır. (eee, ıIı, şey, hı gibi) & & \\
\hline & Dinleyicilerle göz teması kurmaz. & & \\
\hline & Konuşurken öne arkaya veya iki yana sallanır. & & \\
\hline & Konuşurken jest ve mimiklerini, beden dilini etkili kullanmaz. & & \\
\hline & Konuşma esnasında duyulmayacak kadar kısık ses tonu kullanır. & & \\
\hline
\end{tabular}




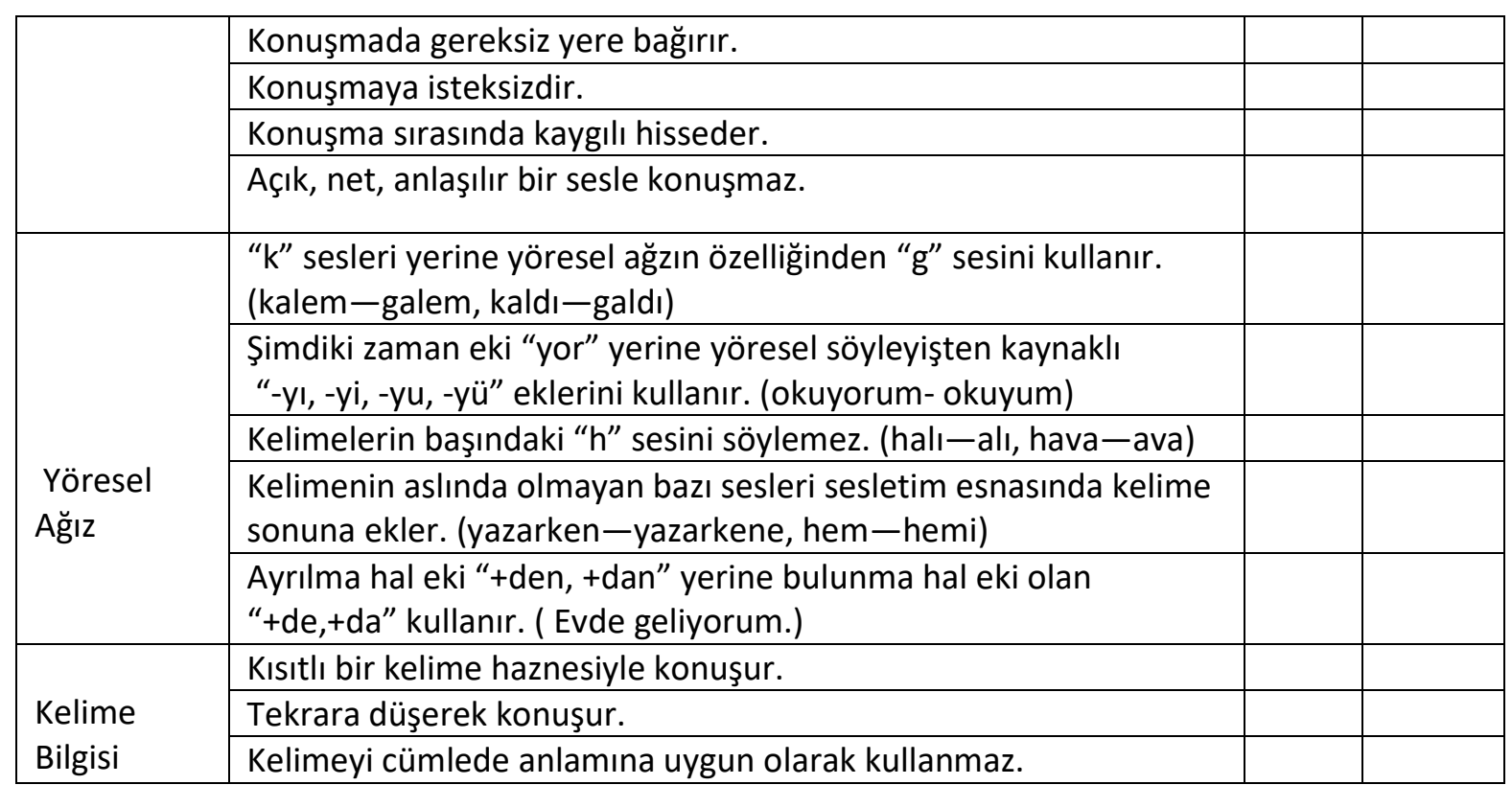

